\title{
Use of residual herbicides in soybean and impact on corn in succession
}

Jamil Constantin', Denis Fernando Biffe', Rubem Silvério de Oliveira Jr.', Ênio Lemes Rosa², Eliezer Antonio Gheno 3 , Fellipe Goulart Machado', Guilherme Braga Pereira Braz ${ }^{4 *}$

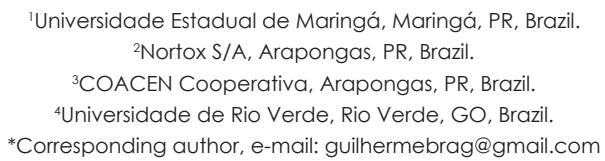

\begin{abstract}
The weed resistance to herbicides has generated the need to adopt different management strategies, listing the tank mixture applications and use of herbicides in different modalities. In this context, it is essential to evaluate the selectivity of these herbicides associations for the crop in which the positioning is performed, as well as the effect of the residual activity of these affecting the crop sown in succession. The objective of this study was to evaluate the control efficacy and selectivity of herbicides applied in pre and post-emergence in soybeans, and the effect of the residual activity of these products on corn cultivated in succession. Two experiments were conducted in field conditions, one for evaluating the effectiveness of the herbicides associations on weed control in soybeans and another to check the selectivity of these for soybeans and the carryover effect for corn cultivated in succession. The experimental design used in both experiments was the completely randomized blocks evaluating nine treatments. All treatments presented efficacy in the control of B. pilosa, D. horizontalis, and C. echinatus. Reductions in soybean yields were observed with the application of diclosulam $\left(25.2 \mathrm{~g} \mathrm{ha}^{-1}\right)$ in pre or postemergence. The association among glyphosate + trifluralin + cloransulam $(720+1350+33,6 \mathrm{~g}$ $\mathrm{ha}^{-1}$ ) caused reductions in soybean yield. None of the treatments used in soybeans affected the corn yield grown in succession.
\end{abstract}

Keywords: carryover, chemical control of weeds, Glycine max, Zea mays

Introduction

The cases of herbicide-resistant weed biotypes have been aggravating at each year, consisting in one of the main bottlenecks within the agricultural production systems. Among the cases of herbicide resistance, those related to glyphosate have been causing the greater concerns for the professionals involved with agriculture (Moreira et al., 2010).

The benefits originated from $R^{\circledR}$ soybean are undeniable, being possible to observe, among the advantages of the cultivation of these varieties, the possibility of the glyphosate utilization, which possess a broad action spectrum and low residual activity, beside the control of resistant weeds to other action mechanisms (Menegatti e Barros, 2007). With the passing of years, some of the initially previewed benefits have not been proven, such as the dispensability of herbicide utilization in pre-emergence (Matsuo et al., 2009). The non-utilization of herbicides in pre-emergence and the intense glyphosate application did contribute to the higher selective pressure of weeds which are resistant to this active ingredient. (Vencill et al., 2012).

Among the strategies which might be utilized aiming the reduction in the selective pressure of resistant weeds, stand out the application of herbicides in associations and the utilization of the active ingredient in a different 
application modality from which it is traditionally positioned. The association within herbicides with different action mechanisms occasions the increase in the control spectrum of the infesting community; this, implicitly, means that the plant shall need to dispose of a higher set of mechanisms, aiming the survival of the action provoked by the applied products (Jhala et al., 2013).

The utilization of the herbicide in a new modality of application turns possible for it to act in the control of the infesting community in different ways; for example, the imazethapyr is traditionally utilized in soybean pre-emergence, aiding in the control of the already emerged weeds, however, when applied in the preemergence of the crop, it presents an excellent residual for the control of some weeds which compose the soil seed bank (Walsh et al., 2015).

By opting for the application of associations or for the utilization of herbicides in new modalities, it is fundamental to proceed studies aiming to evaluate the selectivity of these treatments for the crop which is intended to be positioned. In the cases in which the selectivity gauging is not performed, it is common to observe damages to the crop development (Fornazza, 2016). Another problematic related to this type of positioning is specially observed in regions in which systems of crop rotation are implanted, where the residual activity of a product presents the risk of affecting the development of the crop sown in succession (Santos et al., 2012; Gheno et al., 2015).
The aim of this work was then to evaluate the efficacy in the control of weeds and the selectivity of herbicides applied in pre and postemergence of $R^{\circledR}{ }^{\circledR}$ soybean, besides the effect of residual activity of these over corn cultivated in succession.

\section{Material and Methods}

Two experiments were conducted in a property located in the municipality of Mandaguaçu (PR), with the first experiment in the period from October 14, 2014 to March 4, 2015, and the second experiment from October 14, 2014 to July 23, 2015. The experiment 1 was specifically conducted to evaluate the efficacy of the management systems on the weed control in $\mathrm{RR}^{\circledR}$ soybean, while the Experiment 2 evaluated the selectivity of these for the soybean and the carryover effect for corn cultivated in succession. The El was installed under the coordinates: $23^{\circ} 14^{\prime} 20.76^{\prime \prime} \mathrm{S}$ and 52 $00^{\prime} 21.41^{\prime \prime} \mathrm{W}$, at 466 meters of altitude, and the E2 under the coordinates $23^{\circ} 14^{\prime} 22.73^{\prime \prime} S$ e $52^{\circ} 00^{\prime} 24.19^{\prime \prime} \mathrm{O}$, at 466 meters of altitude.

The predominant climate in the municipality where the experiments were conducted, according to Köppen classification, is of the Cfa type - humid mesothermic, with hot summers and scarce frosts, tendency of rain concentration in the summer months, without a defined dry season. The averages of the hot months are superior to $22^{\circ} \mathrm{C}$, and in the colder months, inferior to $13^{\circ} \mathrm{C}$. The precipitation data observed during the conduction of the experiments are found in Figure 1.

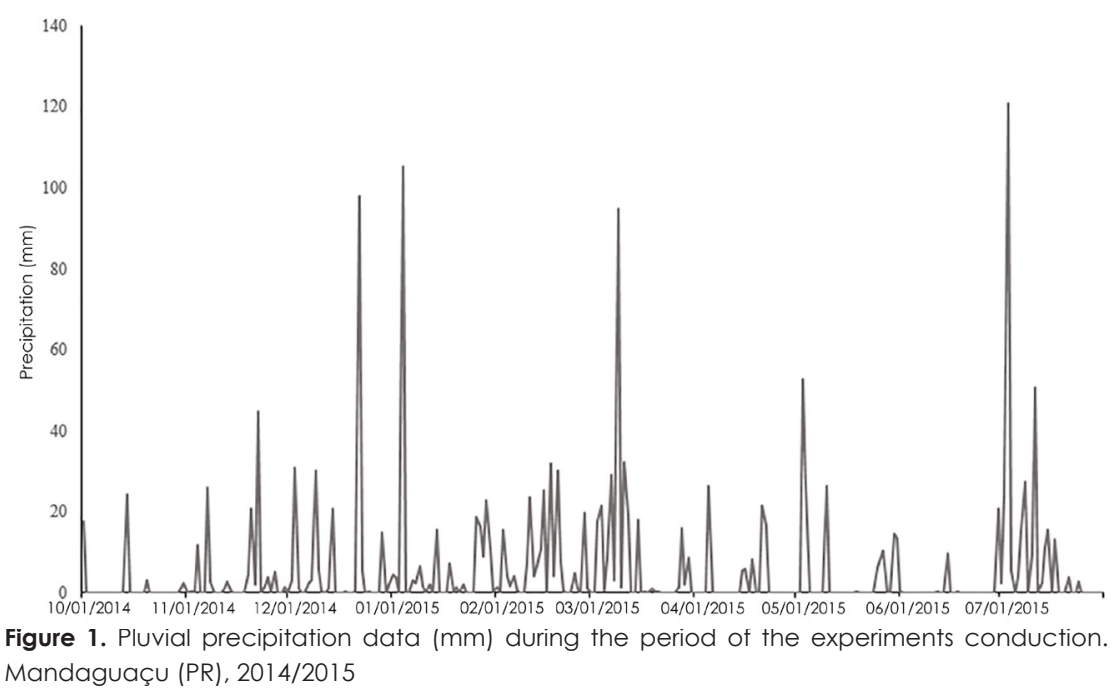


The soil of the experimental area presented a pH in $\mathrm{CaCl}_{2}$ of 5,$6 ; 3,1 \mathrm{cmol}_{\mathrm{c}} \mathrm{dm}^{-3} \mathrm{Of} \mathrm{H}^{+}$ $+\mathrm{Al}^{+3} ; 3,5 \mathrm{cmol}_{\mathrm{c}} \mathrm{dm}^{-3}$ of $\mathrm{Ca}^{+2} ; 1 \mathrm{cmol}_{\mathrm{c}} \mathrm{dm}^{-3}$ of $\mathrm{Mg}^{+2}$; $0,35 \mathrm{cmol}_{\mathrm{C}} \mathrm{dm}^{-3}$ of $\mathrm{K}^{+} ; 19 \mathrm{mg} \mathrm{dm}^{-3}$ of $\mathrm{P} ; 2,9 \mathrm{~g} \mathrm{dm}^{-3}$ of M. $0 . ; 640 \mathrm{~g} \mathrm{~kg}^{-1}$ of clay $141 \mathrm{~g} \mathrm{~kg}^{-1}$ of silt, $219 \mathrm{~g} \mathrm{~kg}^{-1}$ of sand. The area in question lied uncultivated, and no species had been cultivated in the last three months. The desiccation preceding the sowing of the soybean crop was performed on October 14,2014 , through application of the triple mixture of glyphosate $+2,4-\mathrm{D}$ amine + chlorimuron-ethyl $(2160+670+25$ g e.a. ou i.a. ha-1).

Either for the soybean as for the corn, the cultural practices were performed according with the recommended, proceeding to the insect (pests) and disease control, not allowing these to influence the development of the crops.

\section{Control efficacy (El)}

The utilized experimental design was in randomized blocks, with 9 treatments and four repetitions (Table 1). The parcels presented dimensions of $5 \mathrm{~m}$ of length and $4,5 \mathrm{~m}$ of width $\left(22,5 \mathrm{~m}^{2}\right)$, considering as useful area for the evaluations the central part of the parcels, except for $0,5 \mathrm{~m}$ of each extremity.

Table 1. Relation of the management systems of the herbicides and respective dosages evaluated in the Experiments 1 and 2. Mandaguaçu (PR), 2014/2015

\begin{tabular}{|c|c|c|c|}
\hline Application $\mathrm{A}^{\Perp} \Perp$ & $\begin{array}{c}\text { Dosages } \\
\left(\mathrm{g} \mathrm{ha}^{-1}\right)\end{array}$ & Application B21 & $\begin{array}{c}\text { Dosages } \\
\left(\mathrm{g} \mathrm{ha}^{-1}\right)\end{array}$ \\
\hline 1. Paraquat+trifluralin+imazaquim & $400+1350+161$ & glyphosate & $720^{3 /}$ \\
\hline 2. Paraquat+trifluralin+imazethapyr & $400+1350+100$ & glyphosate & 720 \\
\hline 3. Paraquat+trifluralin+diclosulam & $400+450+25,2$ & glyphosate & 720 \\
\hline 4. Paraquat & 400 & glyphosate+trifluralin+imazaquim & $720+1350+161$ \\
\hline 5. Paraquat & 400 & glyphosate+trifluralin+imazethapyr & $720+1350+100$ \\
\hline 6. Paraquat & 400 & glyphosate+trifluralin+diclosulam & $720+450+25,2$ \\
\hline 7. Paraquat & 400 & glyphosate+trifluralin+cloransulam & $720+1350+33,6$ \\
\hline 8. Paraquat & 400 & glyphosate & 720 \\
\hline 9. Paraquat & 400 & No herbicide & - \\
\hline
\end{tabular}

The "A" application was performed on November 01, 2014 (08h40min, with duration of 20 minutes), in conditions of soybean preemergence ("Apply-Plant"). In the moment of this application, the soil was humid, the temperature and air humidity were $24^{\circ} \mathrm{C}$ and $68 \%$, respectively, clouded sky and winds of 1,2 $\mathrm{km} \mathrm{h}^{-1}$. The "B" application was performed on December 02, 2014 (09h20min, with duration of 30 minutes), in post-emergence of soybean crop, with the plants in the V3/V4 phenological stadium. In the moment of application, the soil was humid, the air temperature was $24^{\circ} \mathrm{C}$, the air relative humidity was $70 \%$, clear sky without clouds and winds of $2 \mathrm{~km} \mathrm{~h}^{-1}$.

In all applications (applications "A" and "B") a $\mathrm{CO}_{2}$ based backpack sprayer with constant pressure was utilized, equipped with four XR-110.02 sprayer nozzles, spaced 0,5 m from each other (application strip of $2 \mathrm{~m}$ ), under pressure of $38 \mathrm{lb} \mathrm{pol}{ }^{2}$. These application conditions proportioned the equivalent to $200 \mathrm{~L}$ $\mathrm{ha}^{-1}$ of spray.
The crop sowing was performed on November 1, 2014 (immediately after the end of the "A" application) utilizing the Monsoy 6210 IPRO variety, in a no-tillage system. 18 seeds were distributed per linear meter in a spacing of 0,45 $\mathrm{m}$ between lines. The seeds were treated with Standak Top, in the dosage of $200 \mathrm{~mL} \mathrm{ha}^{-1}$ and Masterfix turfous inoculant. By occasion of the sowing, the fertilization with $300 \mathrm{~kg} \mathrm{ha}^{-1}$ of the formulated 00-20-18 was performed. The emergence of the soybean seedlings occurred in November 8, 2014, seven days after sowing.

At 23 days after emergence, the weeds found in the parcels of the treatment without the application of herbicides in post-emergence were: hairy beggarticks (Bidens pilosa), Jamaican crabgrass (Digitaria horizontalis) and southern sandbur (Cenchrus echinatus) in infestation densities of 19,27 and 21 plants per $\mathrm{m}^{-2}$, respectively. The weed control percentage was evaluated through visual scale, 0-100\%, where $0 \%$ means absence of symptoms, and $100 \%$ total death of weeds at 23 (soybean in V3/ 
V4), 30 (soybean in R1) and 45 DAE (soybean in R2). The crop yield was obtained through mechanized harvesting (WINTERSTEIGER Classic plot harvester) of seven central lines of the parcels (March 6, 2015), discarding 0,50 meters of each extremity. After the harvest, the humidity content of the grains was evaluated through a portable measurer (MiniGAC model) and the humidity was corrected to $14 \%$.

Selectivity for soybean and carryover for corn in second harvest (E2)

The utilized experimental design was in randomized blocks, with 9 treatments and six repetitions (Table 1), with the parcels presenting dimensions of $5 \mathrm{~m}$ length and $4,5 \mathrm{~m}$ width $\left(22,5 \mathrm{~m}^{2}\right)$. Was considered as useful area for the evaluations the central part of the parcels, except for $0,5 \mathrm{~m}$ of each extremity. The equipment utilized for the applications, as well as its adjustments (pressure, number of nozzles, type of nozzle and application rate) were the same as those described for the Experiment 1.

All experimental units were hoed during the entire soybean development cycle, aiming to eliminate the effect of weed competition over the crop yield, leaving the plants exposed only to the effect of the herbicides.

The "A" application was performed on November 1, 2014, (08h00min, with duration of 40 minutes), in conditions of pre-emergence of the soybean crop ("Apply-Plant"). In the moment of this application, the soil was humid, the air temperature was $23^{\circ} \mathrm{C}$, the air relative humidity was $70 \%$, clouded sky and winds of $1,2 \mathrm{~km} \mathrm{~h}^{-1}$. The "B" application was performed on December 2, 2014 (08h40min, with duration of 40 minutes), in post-emergence of soybean crop, with the plants in phenological stadium V3/V4. In the moment of this application, the soil was humid, the air temperature was $24^{\circ} \mathrm{C}$, the air relative humidity was $75 \%$, clear sky without clouds and winds of $2,5 \mathrm{~km} \mathrm{~h}^{-1}$.

The crop sowing was performed on November 01, 2014, utilizing the Monsoy 6210 IPRO variety, in a no-tillage system. 18 seeds were distributed per linear meter in a spacing of $0,45 \mathrm{~m}$ between lines. The seeds were treated with Standak Top, in the dosage of $200 \mathrm{~mL} \mathrm{ha-1}$ and Masterfix turfous inoculant. By occasion of the sowing, fertilization with com $300 \mathrm{~kg} \mathrm{ha}^{-1}$ of the formulated 00-20-18 was performed. The emergence of the soybean seedlings occurred in November 8, 2014, seven days after sowing.

The phytointoxication of the crop was evaluated through the scale proposed by EWRC (1964), where 1 represents the absence of symptoms, and 9 represents the total death of plants, performed at 7 (soybean in V1), 14 (soybean in V2), 30 (soybean in R1) and 45 (soybean in R2) days after soybean emergence (DAE). Furthermore, percentage evaluations of the canopy closure of the crop at 30 and 45 DAE were also performed, as well as the height of the soybean plants at 45 DAE (sampling performed in 10 plants per parcel). Lastly, the crop yield was obtained through mechanized harvesting (04/03/2015) of seven central lines of the parcels, discarding 0,50 meters of each extremity, proceeding to the humidity correction according to the same methodology utilized the El.

The second part of this work consisted in evaluating the effects of the herbicides applied on soybean over the development of the corn cultivated in succession, with the sowing of this crop being performed in the same experimental units which were treated with the herbicides on soybean.

The corn sowing was performed on March 5, 2015 (124 and 93 days after the applications of " $A$ " and " $B$ ", respectively) utilizing the simple hybrid $2 \mathrm{~B} 710 \mathrm{HR}$ (average size and early cycle), in a no-tillage system. 3 seeds were distributed per linear meter in a spacing of 0,45 meters between lines. By occasion of the sowing the fertilization with $400 \mathrm{~kg} \mathrm{ha}^{-1}$ of the formulated 04-14-08 was performed. The emergence of corn seedlings occurred on March 11, 2015, six days after sowing. Such as in the selectivity experiment of soybean herbicides, the experimental units sown with corn were also hoed during the entire development cycle of the crop.

The phytointoxication of the crop was evaluated through the scale proposed by EWRC (1964), being performed at 7 (corn in V1), 14 (corn in V2), 30 (corn in V4) and 45 (corn in V7) DAE. Furthermore, height evaluations of the corn plants were also performed at 30 and 45 DAE 
(sampling performed in 10 plants per parcel) and stand at $45 \mathrm{DAE}$, by the counting of the present plants in $3 \mathrm{~m}$.

Crop yield was obtained through manual harvesting (July 23,2015 ) of seven central lines of the parcels, discarding 0,5 meters of each extremity, proceeding to the humidity correction according with the same methodology utilized for the El.

\section{Statistical analysis}

All the data were subjected to variance analysis by the $F$ test, and the averages compared by the Scott-Knott average grouping test, at 5\% probability. Furthermore, for corn yield, the comparison through average contrast of each treatment containing soybean herbicide application ( $\mathrm{T} 1$ to $\mathrm{T} 8$ ) was performed with the witness without herbicide application (T9).

\section{Results and Discussion}

Control efficacy (EI)

In the evaluation performed at $23 \mathrm{DAE}$, the control notes were based on the residual effect of each treatment over the evaluated weeds, with these results originated from the activity imposed by the utilized herbicides in the applications performed in pre-emergence ("A" application"). The "B" application was performed at 23 DAE of the crop after the control evaluation, and, in this manner, the results of the evaluations performed at 30 and 45 DAE were influenced by the two applications, being no long considered for the control evaluations only the residual effect, but also the efficacy of the applications in post-emergence provided by each treatment.

At 23 DAE there were no differences in the residual control of $B$. pilosa regarding the herbicide which was associated to the mixture of paraquat + trifluralin, demonstrating that any one of the evaluated ALS inhibitors (imazaquim, imazethapyr e diclosulam) presented a similar development in the management of this weed species (Table 2). In average, these treatments presented $82 \%$ of control at $23 \mathrm{DAE}$, which might be considered acceptable in the pre-emergence control of $B$. pilosa and similar to results found for this species by other researchers (Procópio et al., 2006; Oliveira Neto et al., 2010).

The efficacy presented by these treatments in the pre-emergence control of $B$. pilosa is important for agricultural systems which present biotypes of this species with resistance to the inhibiting herbicides of the ALS and/ or Photosystem II (Heap, 2016), seen that the application of these mixtures turns possible the utilization of three distinct action mechanisms, what implies in the decrease of resistant individuals. It is important to highlight, furthermore, that in areas with resistant biotypes to the ALS inhibitors, in order to reach efficacy in the preemergence control of $B$. pilosa, it is fundamental to utilize another action mechanism, since it was already proved that the application modality (pre or post-emergence) does not affect the resistance presented by the species (Guerra et al., 2011; Braz et al., 2014).

Table 2. Control percentage of weed species and soybean yield (PROD) after the application of herbicides in pre and post emergence of the crop. Mandaguaçu (PR), 2014/2015

\begin{tabular}{|c|c|c|c|c|c|c|c|c|c|c|c|c|c|}
\hline \multirow{3}{*}{ Treatments } & \multicolumn{11}{|c|}{$\%$ of control (DAE) } & \multirow{3}{*}{\multicolumn{2}{|c|}{ 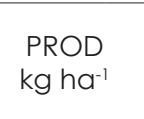 }} \\
\hline & \multicolumn{4}{|c|}{ B. pilosa } & \multicolumn{4}{|c|}{ D. horizontalis } & \multicolumn{3}{|c|}{ C. echinatus } & & \\
\hline & \multicolumn{2}{|c|}{$23^{3 /}$} & \multicolumn{2}{|l|}{30} & \multicolumn{2}{|c|}{$23^{3 /}$} & \multicolumn{2}{|l|}{30} & \multicolumn{2}{|c|}{$23^{3} /$} & 30 & & \\
\hline 1. PAR+TRI+IMZㅍ/ GLYㄴ & 83,8 & $a$ & 98,5 & $a$ & 97,8 & $a$ & 100 & $a$ & 81,3 & $a$ & 100 & 4263,9 & $a$ \\
\hline 2. PAR+TRI+IZTㅆ / GLY리 & 85 & $a$ & 98,8 & a & 98,3 & a & 100 & a & 83,5 & a & 100 & 4297,2 & a \\
\hline 3. PAR+TRI+DIC $\stackrel{1 /}{/}$ GLYㄴ & 86,3 & $a$ & 98,8 & $a$ & 97,8 & $a$ & 100 & $a$ & 83 & $a$ & 100 & 4033,3 & a \\
\hline 4. $P A R \Perp 1 / ~ G L Y+T R I+\mid M Z \underline{2 /}$ & 0 & $b$ & 96,3 & $b$ & 0 & $b$ & 91,8 & $b$ & 0 & $b$ & 83 & 4088,9 & $a$ \\
\hline 5. PAR $\Perp$ / GLY+TRI+IZT니 & 0 & $b$ & 98 & $a$ & 0 & $b$ & 91,3 & $b$ & 0 & $b$ & 83 & 4113,9 & $a$ \\
\hline 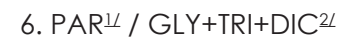 & 0 & $b$ & 98 & $a$ & 0 & $b$ & 92,5 & $b$ & 0 & $\mathrm{~b}$ & 84,3 & 3841,7 & $a$ \\
\hline 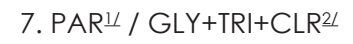 & 0 & $b$ & 96,3 & $b$ & 0 & $b$ & 91,3 & $b$ & 0 & $b$ & 83 & 4188,9 & $a$ \\
\hline 8. PAR $\stackrel{1}{ } /$ / GLY $\underline{2 L}$ & 0 & $b$ & 94,3 & c & 0 & $b$ & 88,8 & $b$ & 0 & $b$ & 81,8 & 3780,6 & $a$ \\
\hline 9. $\mathrm{PAR} \Perp \Perp$ / No herbicide & 0 & $\mathrm{~b}$ & 0 & $d$ & 0 & $a$ & 0 & C & 0 & $b$ & $0 \mathrm{c}$ & 2600 & $b$ \\
\hline $\mathrm{F}$ & 766,1 & & 4444,4 & & 65744,60 & & 753,29 & & 4372,17 & & $1547,69^{*}$ & $6,97^{*}$ & \\
\hline CV (\%) & 10,8 & & 1,13 & & 1,17 & & 2,76 & & 4,54 & & 1,98 & 10,11 & \\
\hline
\end{tabular}


For the evaluation control performed at $30 \mathrm{DAE}$, excluding the treatment in which no application was performed in postemergence of the crop, all the remaining treatments proportioned satisfactory levels of B. pilosa control. For the triple mixtures applied in post-emergence of soybean, slightly inferior performances (2 to 3\%) were observed when proceeding to the association of imazaquim or cloransulam to glyphosate + trifluralin, comparing to the treatments applied with imzethapyr or diclosulam.

For the treatments in which only glyphosate was utilized in post-emergence, the application benefit of products which present residual activity in soybean pre-emergence might be verified, seen that these treatments provide a slight increase in the control of B. pilosa comparing with the treatment in which isolated paraquat was applied in pre-emergence, complemented with glyphosate isolated in post-emergence. The paraquat presents a very low residual activity on the soil, with its microbial degradation much faster after the application (Carr et al., 1985)

At $23 \mathrm{DAE}$, in all treatments in which the mixture of herbicides with the paraquat in the "A" application was proceeded, the control levels of $D$. horizontalis were elevated. The efficacy observed in the pre-emergence control of $D$. horizontalis is likely related to the presence of trifluralin in the composition of the triple association, seen that this herbicide presents a known suppressive action over Poaceae. Francischini et al. (2012) reported the efficacy of isolated trifluralin in the pre-emergence control of $D$. horizontalis when utilized in sunflower crop, however, in this referred work, the authors evaluated a higher dosage of the herbicide.

It is worth noting that in the evaluation performed at $30 \mathrm{DAE}$, the control levels are reflection of the herbicides applied in soybean post-emergence, added of the residual control provided by the substances applied in preemergence of the crop. In this perspective, it is possible to verify a satisfactory control of $D$. horizontalis in all treatments in which herbicide application in soybean post-emergence were performed. In this occasion, higher control levels of this species were obtained with the combination of herbicides which present residual activity, applied in soybean pre-emergence, followed by complementation with isolated glyphosate in post-emergence.

In the treatments with herbicides which presented residual activity, applied in preemergence (T1, T2 e T3), the weed control levels were elevated since the initial phases of the soybean development. This fact is very important, since it is possible to prevent the early interference of weed species in areas where the infestation is higher and/or when the weeds emerge too early. In experiment containing infestation similar and superior to that found in the area in which the present work as conducted, the weed community in coexistence with the crop was able to affect the yield from 17 and 11 days after soybean emergence (low and high infestation, respectively) (Silva et al., 2009).

At 23 DAE of the crop, all treatments which contained herbicides with residual activity associated with the paraquat presented efficacy in the pre-emergence control of $C$. echinatus, with no differences being observed in the development of these treatments.

In the evaluation performed at $30 \mathrm{DAE}$, all treatments with herbicide applications in soybean post-emergence presented efficacy over C. echinatus. Similarly to the observed for $D$. horizontalis, higher control levels of $C$. echinatus were obtained with the combination of herbicides which possess residual activity applied in soybean post-emergence (paraquat + trifluralin + ALS inhibitor), followed by complementation with isolated glyphosate in post-emergence. This behavior demonstrates that in areas with combined infestation of both species, the utilization of a same treatment might provide the efficient control of both Poaceae.

At 45 DAE, all treatments in which some herbicide was adopted in soybean postemergence presented $100 \%$ control of the three evaluated weed species (data not presented). A fact to be highlighted is that even with no differences in the control at 45 DAE of none of the three weed species evaluated in the present work for the utilization of isolated glyphosate in post-emergence with other treatments 
containing association of herbicides, for areas with an elevated number of propagules in the soil seed bank, the utilization of these associations becomes important, since it allows a reduction in the emergence of new flows, seen that these herbicides present residual activity (trifluralin, imazaquim, imazethapyr, diclosulam and cloransulam-methyl).

All treatments with herbicide application in post-emergence of the crop presented a superior yield compared with the treatment in which no management strategies of the infesting community were adopted (Table 2). The reduction in grain yield observed in the treatment in which herbicides in soybean postemergence were not utilized is related to the interference of weeds which emerged after the crop sowing, once that in this treatment (T9) there was no utilization of products which present residual effect in the application performed in pre-emergence.

Selectivity for soybean and carryover for corn in second harvest (E2)

In Table 3 are presented the soybean phytointoxication data after the application of herbicides for weed management. Concerning symptoms provoked by the herbicides applied in post-emergence (phytointoxication evaluations performed at 7 and $14 \mathrm{DAE}$ ), these were verified only in the treatment containing the diclosulam in association with paraquat + trifluralin. Such symptoms were light (Grade 2 in the EWRC scale, 1964) and characterized by the yellowing of the younger leaves in some plants present in the experimental units.

Table 3. Phytointoxication evaluation of the crop through the EWRC scale (1964) after the application of herbicides in pre and post-emergence of $R^{\circledR}$ soybean. Mandaguaçu (PR), 2014/2015

\begin{tabular}{|c|c|c|c|c|}
\hline \multirow{2}{*}{ Treatments } & \multicolumn{4}{|c|}{ Phyłointoxication } \\
\hline & $14 \mathrm{DAE}$ & $23 \mathrm{DAE}^{-3 /}$ & $30 \mathrm{DAE}$ & $45 \mathrm{DAE}$ \\
\hline 1. PAR+TRI+IMZㅍ / GLYㄴ & 1 & 1 & 2 & 2 \\
\hline 2. PAR+TRI+IZTㅍ / GLYㄴ & 1 & 1 & 2 & 2 \\
\hline 3. PAR+TRI+DIC $\Perp / G L Y \underline{2 l}$ & 2 & 1,7 & 2 & 2 \\
\hline 4. PAR $\stackrel{1}{ } /$ GLY+TRI+IMZ리 & 1 & 1 & 2,7 & 2,7 \\
\hline 5. PAR $\Perp$ / GLY+TRI+|ZTㄹ & 1 & 1 & 2,7 & 2,7 \\
\hline 6. PAR $\Perp$ / GLY+TRI+DICㄹ & 1 & 1 & 3,3 & 3,2 \\
\hline 7. PAR $\Perp / G L Y+T R I+C L R \stackrel{21}{ }$ & 1 & 1 & 2,8 & 2,7 \\
\hline 8. PAR $\Perp$ / GLY 21 & 1 & 1 & 2 & 2 \\
\hline 9. $\mathrm{PAR} \Perp /$ No herbicide & 1 & 1 & 1 & 1 \\
\hline
\end{tabular}

At 30 DAE (7 days after "B" application), all herbicides applied in soybean postemergence caused injuries to the treated plants, being the visual symptoms more evident in the treatments in which the mixture of glyphosate + trifluralin + diclosulam was utilized. In a new evaluation performed at $45 \mathrm{DAE}$, the symptoms provoked by the herbicides applied in postemergence persisted, without, however, causing more pronounced injuries.

On Table 3 are presented the results of different performed evaluations aiming to verify the influence of the different herbicides over the $R^{\circledR}{ }^{\circledR}$ soybean crop development. At $30 \mathrm{DAE}$, it is possible to verify the lower values for the percentage of canopy closure in the treatments in which products in association with glyphosate were utilized in the " $\mathrm{B}$ " application. The remaining treatments which only received the application of glyphosate in soybean post-emergence ( $T 1$, T2, T3 and T8) and the parcels without application (T9), presented similar percentages of canopy closure of the crop.

In new evaluation performed at 45 $D A E$, it is possible to observe a negative effect of the diclosulam (associated with trifluralin and with paraquat or glyphosate) concerning the canopy closure in soybean, once that either in the pre-emergence applications(T3) and in the post-emergence applications (T6) of the crop, the presence of this herbicide presented lower values for this variable. Beside these treatments, a lower percentage of soybean canopy closure was observed in the parcels which received application in post-emergence of the triple mixture of glyphosate, trifluralin and cloransulam-methyl. 
Table 4. Canopy closure of the crop, plant height and grain yield of soybean after the application of herbicides in pre and post-emergence of $R^{\circledR}{ }^{\circledR}$ soybean . Mandaguaçu (PR), 2014/2015

\begin{tabular}{|c|c|c|c|c|c|c|}
\hline \multirow{2}{*}{ Treatments } & \multicolumn{4}{|c|}{$\%$ of closure } & \multirow{2}{*}{$\frac{\text { Height }(\mathrm{cm})}{45 \mathrm{DAE}}$} & \multirow{2}{*}{$\frac{\text { Yield }}{\mathrm{kg} \mathrm{ha}^{-1}}$} \\
\hline & $30 \mathrm{DAE}^{3}$ & & $45 \mathrm{DAE}$ & & & \\
\hline 1. PAR+TRI+IMZㅍ / GLYㄹ & 76,8 & $a$ & 97,3 & a & 42,2 a & 4488,9 \\
\hline 2. $P A R+T R I+\mid Z T \perp / G L Y \underline{\perp}$ & 78 & $a$ & 97,2 & $a$ & 41,5 a & 4457,4 \\
\hline 3. PAR+TRI+DIC $\Perp /$ GLY 21 & 77,7 & $a$ & 92,5 & $b$ & $39,7 \quad a$ & 4277,8 \\
\hline 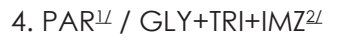 & 71,7 & $b$ & 96,3 & a & 40 a & 4357,4 \\
\hline 5. PAR $\Perp$ / GLY+TRI+|ZT $\Perp$ & 72,7 & $b$ & 95 & a & 39,2 a & 4385,2 \\
\hline 6. PAR $\Perp / G L Y+T R I+D I C \stackrel{21}{ }$ & 65,5 & C & 81,8 & c & $36,3 \quad b$ & 4024,1 \\
\hline 7. PAR $\Perp / G L Y+T R I+C L R \perp$ & 73,5 & $b$ & 90,8 & b & $34,8 \quad b$ & 4207,4 \\
\hline 8. PAR $\Perp$ / GLY2L & 77,5 & $a$ & 95,7 & a & 41,3 a & 4474,1 \\
\hline 9. $\mathrm{PAR}^{\Perp} /$ / No herbicide & 79,2 & $a$ & 98 & a & $43 a$ & 4559,3 \\
\hline $\mathrm{F}$ & $9,90^{*}$ & & $43,05^{*}$ & & $4,06^{*}$ & $3,13^{*}$ \\
\hline CV (\%) & 4,53 & & 2,02 & & 6,75 & 5,29 \\
\hline
\end{tabular}

The observed results for the evaluations of canopy closure percentage of the crop presented a positive relation with the phytointoxication notes, seen that in the treatments where more elevated injuries were observed in soybean plants, higher reductions were also verified in the canopy closure percentage of the crop.

The treatments 6 e 7 , respectively composed by the application in postemergence of the mixture between glyphosate + trifluralin + diclosulam and glyphosate + trifluralin + cloransulam-methyl, were the only which interfered in the soybean growth rate, observing plants with lower statures in these treatments, compared with the remaining treatments. In a certain way, the observed results for the height of soybean plants follow the tendency of the canopy closure and phytointoxication evaluations, observing greater damages to the crop with the utilization of the Treatments 6 and 7 .

The treatments which negatively affected the soybean yield were those which received application of diclosulam (associated with trifluralin and paraquat or glyphosate), not matterring if this treatment was utilized in pre (T3) or post-emergence (T6) of the crop (Table 4). Beside these treatments, a teduction in grain yield was verified when applying the triple mixture of glyphosate, trifluralin and cloransulam in post emergence of $R^{\circledR}{ }^{\circledR}$ soybean. The yield reductions in soybean grains observed in Treatments 3, 6 and 7 compared to Treatment 9 (without residual in pre-emergence and without herbicide application in post-emergence) were of 6,17, 11,73 and $7,71 \%$, respectively.
Despite diclosulam and trifluralin present register for utilization in soybean pre-emergence, reductions in the yield of this crop with the application of these herbicides (in this modality) were already reported (Biffe, 2012; Fornazza, 2016), demonstrating that soybean might have its tolerance to these products affected by the cultivation conditions (soil texture, compaction, climate) or yet, by varietal differences.

Excluding trifluralin, the remaining residual herbicides evaluated in the present work did not present register for being utilized in the corn crop. The elevated persistence that some of these herbicides possess might affect the corn development when sown in succession, once that, in the literature, negative effects for this crop were already reported in function of herbicides persistence applied in different cultivated species (Mancuso et al., 2011; Gheno et al., 2016).

In the different phytointoxication evaluations performed, no injury symptoms caused by the herbicides to the corn plants were observed (data not presented). Nevertheless, for this type of experiment, only visual evaluations are not enough for concluding about the carryover occurrence possibility of the herbicides, since it is possible to observe reductions in the yield of crops even if these have not presented visual symptoms of injury (Steckel et al., 2015).

In the two evaluations of plant height, performed at 30 and 45 DAE none of the herbicide treatments applied in the management of weeds on soybean affected this variable - answer in the corn sown in succession (Table 5). 
Tabela 5. Plant height, stand and grain yield of corn after the application of herbicides in pre and post-emergence of $R^{\circledR}{ }^{\circledR}$ soybean . Mandaguaçu (PR), 2014/2015

\begin{tabular}{|c|c|c|c|c|c|}
\hline \multirow{2}{*}{ Treatments } & \multicolumn{2}{|c|}{ Height (cm) } & \multirow{2}{*}{$\begin{array}{l}\text { Stand } \\
45 \mathrm{DAE}\end{array}$} & \multirow{2}{*}{$\begin{array}{c}\text { Yield } \\
\text { kg ha-1 }^{-1}\end{array}$} & \multirow{2}{*}{$\begin{array}{l}\text { YieldL } \\
\text { pValue }\end{array}$} \\
\hline & $30 \mathrm{DAE}$ & $45 \mathrm{DAE}$ & & & \\
\hline 1. PAR+TRI+IMZ피 / GLY리 & 32,5 & 52,3 & 8,8 & 8455,8 & 0,87 \\
\hline 2. PAR+TRI+IZTㅆ / GLY니 & 32,5 & 51 & 8,8 & 8518,6 & 0,93 \\
\hline 3. PAR+TRI+DICㅍ / GLY리 & 34,2 & 50,8 & 8,3 & 8536,4 & 0,77 \\
\hline 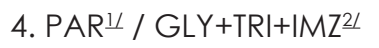 & 34,2 & 52,7 & 8,3 & 8471,5 & 0,88 \\
\hline 5. PARㄴ / GLY+TRI+|ZTㄹ & 33,2 & 51,2 & 8,7 & 8623,3 & 0,97 \\
\hline 6. PAR $1 /$ / GLY+TRI+DIC $\underline{2}$ & 35,7 & 51,7 & 8,3 & 7084,9 & 0,07 \\
\hline 7. $P A R \perp 1 / G L Y+T R I+C L R \underline{2 I}$ & 33,5 & 52,8 & 8,8 & 7372,7 & 0,15 \\
\hline 8. PARㅍ / GLY리 & 32,5 & 49,7 & 8,7 & 8565,7 & 0,97 \\
\hline 9. PAR $\Perp$ / No herbicide & 36,2 & 50,3 & 8,5 & 8591,9 & - \\
\hline $\mathrm{F}$ & $1,07^{\text {ns }}$ & $0,41^{\mathrm{ns}}$ & $0,51^{\mathrm{ns}}$ & $0,94^{\mathrm{ns}}$ & - \\
\hline CV (\%) & 9,52 & 7,98 & 7,42 & 17,62 & - \\
\hline
\end{tabular}

At 45 DAE the counting of the number

of the emerged corn plants was also performed, not being verified differences in the stand in function of the residual activity of the herbicides applied in the soybean. The maintaining of the adequate stand for the corn is fundamental so that reductions in the yield of this crop do not come to be observed, considering that, differently from other cultivated species, the corn does not present an elevated plasticity, and as such the stand of plants consists in an important yield component (Piana et al., 2008).

Just as for the other variables evaluated in the present work, the grain yield of the corn grains was not influenced by the residual activity (carryover) of the different herbicide treatments applied in the management of weed species in the soybean crop. The elevated volume of precipitations among the herbicide application on soybean and in the corn sowing, 826 and $697,4 \mathrm{~mm}$, respectively, for the "A" and "B" applications (Figure 1), might have contributed for the dissipation of these products on the soil, occasioning that the residual activity of the herbicides did not cause negative effects over the corn cultivated in succession.

Despite the absence of statistical differences through the $\mathrm{F}$ test (5\% probability) when comparing corn yield among all treatments, through contrast analysis, confronting each herbicide treatment with the witness (T9), it becomes more evident the probability that each of these has in compromising the corn yield (Table 5).
Based on the observed results for this analysis, a special attention must be directed to the treatments with the utilization of diclosulam and cloransulam (applied in soybean postemergence), which presented probabilities in differing from the witness in values equivalent to 7 and $15 \%$, respectively. This observation becomes more evident when comparing the $p$ values of the remaining treatments, since that the values of T6 and T7 were, respectively, 13 and 6 times lower than the average of the remaining treatments (T1, T2, T3, T4, T5 e T8).

\section{Conclusions}

The herbicides paraquat, glyphosate and its applications with trifluralin and/or diclosulam, imazaquin, imazethapyr or cloransulam presented efficacy in the control of B. pilosa, D. horizontalis and $\mathrm{C}$. echinatus.

Reductions in soybean yield occurred with the usage of diclosulam (25,2 $\left.\mathrm{g} \mathrm{ha}^{-1}\right)$ in association with other herbicides, either in pre or post-emergence applications performed on the crop.

The application of the association of glyphosate + trifluralin + cloransulam $(720+1350$ $+33,6 \mathrm{~g} \mathrm{ha}^{-1}$ ) in soybean post-emergence also reduces the yield of this crop.

None of the herbicide-containing treatments utilized on soybean which possess residual activity (trifluralin, diclosulam, imazaquin, imazethapyr and cloransulam) affect the yield of the corn cultivated in succession. 


\section{References}

Biffe, D.F. 2012. Efeito da aplicação de herbicidas em pré-emergência e de glyphosate em pósemergência, sobre a cultura da soja em solo compactado e não compactado. 88 f. (Tese de Doutorado) - Universidade Estadual de Maringá, Maringá, Brazil.

Braz, G.B.P., Oliveira Jr., R.S., Constantin, J., Osipe, J.B., Takano, H.K., Gheno, E.A. 2014. Atividade residual do pyrithiobac-sodium no controle de plantas daninhas do algodoeiro. Magistra 26: 132-145.

Carr, R.J., Bilton, RF., Atkinson, T. 1985. Mechanism of biodegradation of paraquat by Lipomyces starkeyi. Applied and Environmental Microbiology 49: 1290-1294.

EWRC (European Weed Research Council). 1964. Report of $3^{\text {rd }}$ and $4^{\text {th }}$ meetings of EWRC Committee of Methods in Weed Research. Weed Research 4: 88.

Fornazza, F.G.F. 2016. Seletividade de combinações de herbicidas aplicados em pré e pós-emergência em soja super precoce. 90 f. (Dissertação de Mestrado) - Universidade Estadual de Maringá, Maringá, Brazil.

Francischini, A.C., Santos, Gizelly, G., Constantin, J., Ghiglione, H., Velho, G.F., Guerra, N., Braz, G.B.P. 2012. Eficácia e seletividade de herbicidas do grupo das imidazolinonas aplicados em pós-emergência de plantas daninhas monocotiledôneas na cultura do girassol CL. Planta Daninha 30: 843-851.

Gheno, E.A., Oliveira Jr., R.S.; Constantin, J., Biffe, D.F.; Menezes, C.C.E.; Franchini, L.H.M., Osipe, J.B., Raimondi, R.T. 2015. Carryover of herbicides applied in the pre-emergence of cotton on the corn grown in succession. Revista Brasileira de Herbicidas 14: 155-163.

Gheno, E.A., Oliveira Jr., R.S.; Constantin, J., Takano, H.K., Gemelli, A. 2016. Residual activity of herbicides applied to cotton on crops cultivated in succession. Revista Caatinga 29: 143-152.

Guerra, N., Oliveira Jr., R.S., Constantin, J., Oliveira Neto, A.M., Dan, H.A., Alonso, D.G., Santos, G. Jumes, T.M.C. 2011. Efeito da modalidade de aplicação sobre o controle de Bidens pilosa resistente a herbicidas inibidores da enzima ALS. Global Science and Technology 4: 61-69.

Heap, I. 2016. http://weedscience.org/. <Acesso em 18 Mar. 2016>

Jhala, A.J., Ramirez, A.H.M., Knezevic, S.Z., Ugent, P.V.D., Singh, M. 2013. Herbicide tank mixtures for broad-spectrum weed control in Florida citrus. Weed Technology 27: 129-137.
Mancuso, M.A.C., Negrisoli, E., Perim, L. 2011. Efeito residual de herbicidas no solo ("Carryover"). Revista Brasileira de Herbicidas 10: 151-164.

Matsuo, E., Sediyama, T., Cruz, C.D., Silva, A.A., Oliveira, R.C.T., Nogueira, A.P.O., Tancredi, F.D. 2009. Resistência de genótipos de soja ao herbicida glyphosate. Planta Daninha 27: 10631073.

Menegatti, A.L.A., Barros, A.L.M. 2007. Análise comparativa dos custos de produção entre soja transgênica e convencional: um estudo de caso para o Estado do Mato Grosso do Sul. Revista de Economia e Sociologia Rural 45: 163-183.

Moreira, M.S., Melo, M.S.C., Carvalho, S.J.P., Nicolai, M., Crhistoffoleti, P.J. 2010. Herbicidas alternativos para controle de biótipos de Conyza bonariensis e C. canadensis resistentes ao glyphosate. Planta Daninha 28: 167-175.

Oliveira Neto, A.M., Constantin, J., Oliveira Jr., R.S., Guerra, N., Dan, H.A., Alonso, D.G., Blainski, E., Santos, G. 2010. Estratégias de manejo de inverno e verão visando ao controle de Conyza bonariensis e Bidens pilosa. Planta Daninha 28: 1107-1116.

Piana, A.T., Silva, P.R.F., Bredemeier, C., Sangoi, L., Vieira, V.M., Serpa, M.S., Jandrey, D.B. 2008. Densidade de plantas de milho híbrido em semeadura precoce no Rio Grande do Sul. Ciência Rural 38: 2608-2612.

Procópio, S.O., Menezes, C.C.E., Pires, F.R., Barroso, A.L.L., Cargnelutti Filho, A., Rudovalho, M.C., Morais, R.V., Silva, M.V.V., Caetano, J.O. 2006. Eficácia de imazethapyr e chlorimuronethyl em aplicações de pré-semeadura da cultura da soja. Planta Daninha 24: 467-473.

Santos, G., Francischini, A.C., Constantin, J., Oliveira Jr., R.S. 2012. Carryover proporcionado pelos herbicidas S-metolachlor e trifluralin nas culturas de feijão, milho e soja. Planta Daninha 30: 827-834.

Silva, A.F., Concenço, G., Aspiazú, I., Ferreira, E.A., Galon, L., Freitas, M.A.M., Silva, A.A., Ferreira, F.A. 2009. Período anterior à interferência na cultura da soja-RR em condições de baixa, média e alta infestação. Planta Daninha 27: 57-66.

Steckel, L.E, Stewart, S.D., Steckel, S. 2015. Corn response to POST-Applied HPPD-Inhibitor based premix herbicides with in-furrow and foliarapplied insecticides. Weed Technology 29: 18-23.

Vencill, W.K., Nichols, R.L., Webster, T.M., Soteres, J.K., Mallory-Smith, C., Burgos, N.R., Johnson, W.G., McClelland, M.R. 2012. Herbicide resistance: toward an understanding of resistance development and the impact of herbicideresistant crops. Weed Science 60: 2-30. 
Walsh, K.D., Soltani, N., Shropshire, C., Sikkema, P.H. 2015. Weed control in soybean with imazethapyr applied alone or in tank mix with saflufenacil/dimethenamid-P. Weed Science 63: 329-335. 